\title{
Ecological Risk Assessment of Urban Streams Using Fish Biomarkers of DNA Damage and Physiological Responses
}

\author{
Dae-Yeul Bae1, Usman Atique ${ }^{1}$, Jo Hee Yoon², Byung-Jin Lim², Kwang-Guk An ${ }^{1 *}$ \\ ${ }^{1}$ Department of Bioscience and Biotechnology, Chungnam National University, Daejeon, Republic of Korea \\ ${ }^{3}$ Geum River Environment Research Center, National Institute of Environment Research, \\ Okcheon, Republic of Korea
}

Received: 22 October 2018

Accepted: 24 February 2019

\begin{abstract}
Ecological risk assessment was carried out in two urban streams, viz. Gap Stream (GS) and Miho Stream (MS), in the Geum River Watershed during July 2013-October 2014. The techniques used in this study included multi-level fish biomarkers of DNA damage based on single-cell gel electrophoresis (SCGE) coupled with the study of physiological responses based on 7-ethoxyresorufin- $O$-deethylase (EROD) and acetylcholinesterase (AChE) activities in fish species. Biomarker values of tail DNA (tDNA), tail length $\left(\mathrm{T}_{\mathrm{L}}\right)$, and tail extent moment (TEM) in impacted zone $\left(\mathrm{I}_{\mathrm{z}}\right)$ were 2.0-3.6-fold greater than in controls $\left(\mathrm{C}_{\mathrm{z}}\right)$. Nucleus image analysis showed that the nucleus had circular particle forms in the $\mathrm{C}_{\mathrm{z}}$ as compared with a longitudinal oval form with broken particles from the nucleus in the $\mathrm{I}_{\mathrm{z}}$. Physiological response analysis of EROD and AchE activities indicated that their levels were higher in the $\mathrm{I}_{z}$ than in the $\mathrm{C}_{\mathrm{z}}$. Such DNA damages and greater physiological responses in the $\mathrm{I}_{\mathrm{z}}$ were attributed to chemical contaminants discharged from the wastewater disposal plants and industrial complex. This combination of DNA damage and physiological responses approach can be used as a key tool for early-warning detection of chemical contaminants and concomitant risks to the ecological health of urban streams.
\end{abstract}

Keywords: ecological risk, single-cell gel electrophoresis, heavy metal, DNA damage, 7-ethoxyresorufin-O-deethylase

\section{Introduction}

Ecological risk assessment (ERA), based on molecular-level or biochemical biomarkers, has been highlighted in ecotoxicological and genotoxic research [1-2] dealing with the evaluations of aquatic ecosystems impacted as a result of exposure to one or more chemical stressors such as anthropogenic pollutants [3-4]. The detection approaches of deoxyribonucleic acid (DNA) damage at the level of an individual eukaryotic cell have been previously applied to various research areas such as plant sciences [5-6] and mammal toxicology studies 
[4]. Recently, single-cell gel electrophoresis (SCGE), also known as the comet assay, has been widely applied in DNA damage research as a cost-effective method [78] as well as being a simple and sensitive dose-response technique for measuring deoxyribonucleic acid (DNA) strand breaks in eukaryotic cells of a species [9-10].

The comet assay measures the single/doublestranded DNA breaks, alkali labile sites, DNA crosslinks, base or base pair damage, and apoptotic nuclei in the cells of an organism. The approach of SCGE was originally introduced by Östling and Johanson [11] and later modified by Singh et al. [12]. Since then, aquatic ecologists have used the standard dose-response monitoring approach for detection of molecular-level damages in aquatic organisms [13-14]. In addition to this novel approach, change in physiological responses such as acetylcholinesterase (AChE) activity [15-16] and 7-ethoxyresorufin-O-deethylase (EROD) activity [17] estimation could be used as an excellent barometer (biomarker) in detecting the cause-effect problems at the cellular or sub-cellular levels. Therefore, due to the above-mentioned reasons, such approaches can be considered as integral parts of an early warning (alarm) system, which can provide significantly reliable clues regarding the imminent threats and existing issues in aquatic ecosystem health [18-20].

Previous research on aquatic ecosystem health diagnosis mainly focused on the population responses of aquatic communities such as fish, macroinvertebrate and periphyton [21-24] in relation to various chemical stressors, physical habitat disturbances because of anthropogenic activities as well as channel modifications [25-28]. Such ecosystem risk assessment approaches at the community level were widely applied to reveal the extent of disturbances in aquatic ecosystems in North America [29], Europe [30], Africa [31-32] and Asia [33-34]. In addition, the risk assessments in streams and rivers were originally carried out at the population and organ/tissue level [18, 35-36]. Several disadvantages of these risk assessment studies according to the bioindicator level used were, however, pointed out as their inability to act as an early detection system that could be relied on as in the case of impending severe pollution crises in aquatic ecosystems. Thus, the use of biomarkers such as SCGE, AChE and EROD may provide an excellent nexus leading to unveil some significant clues to identify the causal mechanisms potentially responsible for any type of damage at molecular, cellular, and sub-cellular levels [35, 37-39].

Despite the numerous advantages of early warning detection of problems in ecosystem health, very little is known about DNA-level and physiological-level risk assessments in stream or river ecosystems in Korea. Adams [40] pointed out that the combination of comet assay and physiological assays using fish samples (sentinel species) plays a significant role in risk assessments of aquatic ecosystems. They may act as very effective biomarkers used in detecting the organic matter, toxic chemicals, and heavy metal pollution
[41-44] in urban streams. Moreover, the comet assay is known as a biomarker that is considered one of the best barometers used in assessing DNA damage by oxidative stress responses [12, 45].

Keeping in view the grander importance of the novel techniques as well as the significance of early detection and warning systems in urban streams, the key objectives of this investigation encompassed the analysis of DNA damage using two different sentinel species from benthic and water-column fish communities dwelling in the target urban streams. It also included the measurements of Tail DNA ( $t$ DNA), tail length, and tail extent moments in the control zones (pristine region) to compare with the impacted streams using the comet assay technique. In addition, physiological activities of fish, based on EROD activity and AChE activity, were measured and compared with chemical conditions in the sampling streams.

\section{Experimental}

\section{Sampling and Sampling Sites}

The sampling was conducted in two urban streams, viz. Gap Stream (GS) and Miho Stream (MS), during July 2013-October 2014. Gap Stream is one of main tributaries in the Geum River watershed, and courses through the epicenter of metropolitan Daejeon. The sampling sites were selected in two zones, which are represented as upstream and pristine region (control zone, $\mathrm{C}_{\mathrm{z}}$ ) and downstream and polluted region (impacted zone, $\mathrm{I}_{\mathrm{z}}$ ), based on major point sources within the watershed. The control zone $\left(\mathrm{C}_{\mathrm{z}}\right)$ is mainly surrounded by forest (>about $65 \%$ ), some paddies (about $20 \%$ ) and ordinary fields alongside the stream route, and has riffle-pool morphology with gravel as the dominant substratum. The impacted zone $\left(\mathrm{I}_{\mathrm{z}}\right)$ is largely influenced by Daejeon Industrial Complex (IN CO) besides a wastewater disposal plant (WDP), and merges with Yudeung Stream, which is also running through Daejeon (Fig. 1). Principally, the WDP discharge capacity is approximately $9 \times 10^{5} \mathrm{~m}^{3}$ day $^{-1}$ and the effluents find their way to the impacted zone $\left(\mathrm{I}_{\mathrm{z}}\right)$ in the Gap Stream directly. Fish species and their taxonomic classification were carried out based on their salient body features as described by Kim and Park [47]. The fish sampling was performed in accordance with the modified wading technique [27, 48-49] for assessing stream condition, and the method was derived from the classic Ohio EPA technique [50].

\section{Laboratory Analysis of DNA Damage Detection and Physiological Responses}

Single-cell gel electrophoresis (SCGE) analysis (comet assay) was conducted based on the approach modified from the methods of Singh et al. [12]. After the blood samples were centrifuged for 5 minutes at 


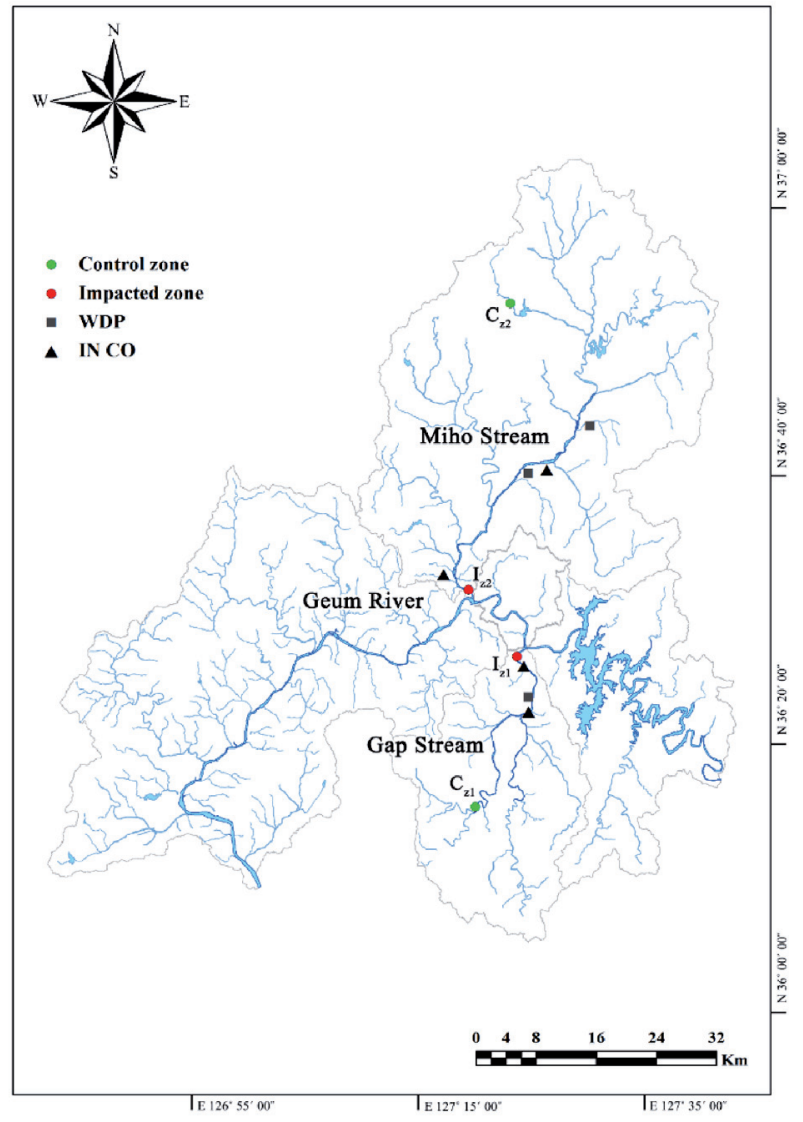

Fig. 1. Watershed maps and sampling zones in Gap Stream $\left(\mathrm{C}_{\mathrm{z} 1}\right.$, $\left.\mathrm{I}_{z 1}\right)$ and Miho Stream $\left(\mathrm{C}_{72}, \mathrm{I}_{72}\right)$; in the figure, the abbreviations of " $\mathrm{C}_{\mathrm{z}}$ " $\left(\mathrm{C}_{\mathrm{z} 1}, \mathrm{C}_{\mathrm{z} 2}\right)$ and " $\mathrm{I}_{\mathrm{z}}$ " $\left(\mathrm{I}_{\mathrm{z} 1}, \mathrm{I}_{\mathrm{z} 2}\right)$ denote the control and impacted zones, respectively; also, "WDP" and "IN CO" indicate major point sources of waste water disposal plants and industrial complexes, respectively.

$3000 \mathrm{rpm}$, the samples with $0.65 \%$ agarose were layered on the pre-coated slide glass using $1 \%$ agarose, and then treated by lysis buffer for 3 hours at $4^{\circ} \mathrm{C}$. The sample slides treated with the lysis buffer were conducted by electrophoresis $(25 \mathrm{~V}, 300 \mathrm{~mA})$ in the buffer solution for 40 minutes. To determine DNA damage, the lengths of nuclear DNA fragments (tail length, $\mathrm{T}_{\mathrm{L}}, \mu \mathrm{m}$ ) and the proportion of DNA in the tail (tDNA, \%) were analyzed. The tail extent moment $\left(\mathrm{T}_{\mathrm{FM}}\right)$ was also estimated as $\mathrm{T}_{\mathrm{L}} \times$ tDNA/100 using a Komet 4.0 comet image analysis system. The analysis of 7-Ethoxyresorufin$O$-deethylase (EROD) activity using liver samples was conducted by the approach modified from the methods of Kennedy and Jones [51]. The formation rate of the product from ethoxyresorufin was calculated from the peak area of different concentrations of resorufin. Acetylcholinesterase (AChE) activity was analyzed using an ABC kit at the Korea Institute of Ocean Science and Technology (KIOST), based on colorimetric assay of Ellman et al. [52]. The frozen $20 \mathrm{mg}$ brain sample was mixed with $1 \mathrm{~mL}$ buffer and homogenized. Then the sample was centrifuged $\left(10,000 \mathrm{~g}, 4^{\circ} \mathrm{C}\right)$ for 10 minutes. Protein quantitative analysis was carried out using the BCA protein assay kit. The microplate reader method was used based on the absorbance measurements at $415 \mathrm{~nm}$.

\section{Heavy Metals and POPs Chemicals Assessment}

Bottom sediment samples of the two sampling streams were procured for heavy metal analysis. The top 5-cm layer of sediments was scooped using sterile stainless steel equipment into autoclaved disposable containers, simultaneously. All extracts were analyzed using an atomic absorption spectrometer (Analyst 800, PerkinElmer, Shelton, CT, USA). The persistent organic pollutants (POPs) were also estimated from the water samples at the different zones of the two urban streams. In total, we analyzed 24 POP chemicals, including agricultural pesticides (1), aromatic hydrocarbons (1), EDCs (2), herbicides (8), insecticides (3), metabolites of medicines (1) and heavy metals (8). The laboratory assessments of POPs chemicals and heavy metals were conducted as described by Eaton and Franson [53] and Segner et al. [54].

\section{Data Analysis}

For the data analysis of biomarkers and bioindicators, an independent two-sample t-test was used for sample

Table 1. Mean values of tail DNA ( $t$ DNA), tail length $\left(\mathrm{T}_{\mathrm{L}}\right)$, and tail extent moment $\left(\mathrm{T}_{\mathrm{EM}}\right)$ in two habitat-type fish collected in the control zone $\left(\mathrm{C}_{\mathrm{z}}\right)$ and impacted zone $\left(\mathrm{I}_{\mathrm{z}}\right)$ of the sampling streams; each value is expressed as mean \pm standard error (SE).

\begin{tabular}{|c|c|c|c|c|c|c|}
\hline Fish type / Location & $\mathrm{n}$ & Total length (mm) & Weight $(\mathrm{g})$ & Tail DNA (\%) & Tail length $(\mu \mathrm{m})$ & Tail extent moment \\
\hline \multicolumn{7}{|c|}{ a) Benthic Species (Pseudogobio esocinus) } \\
\hline $\mathrm{C}_{\mathrm{z}}$ & 14 & $134.36 \pm 4.74$ & $20.37 \pm 2.16$ & $21.55 \pm 0.50^{\dagger}$ & $43.34 \pm 0.89^{\dagger}$ & $12.90 \pm 0.50^{\dagger}$ \\
\hline $\mathrm{I}_{\mathrm{z}}$ & 17 & $120.18 \pm 5.88$ & $17.04 \pm 2.81$ & $43.90 \pm 0.58^{*, \dagger}$ & $92.42 \pm 1.31^{*, \dagger}$ & $46.40 \pm 1.04^{*, \dagger}$ \\
\hline $\mathrm{C}_{\mathrm{z}}$ & 8 & $110.88 \pm 6.01$ & $14.42 \pm 2.43$ & $16.60 \pm 0.51^{\dagger}$ & $28.56 \pm 0.80^{\dagger}$ & $7.19 \pm 0.38^{\dagger}$ \\
\hline $\mathrm{I}_{\mathrm{z}}$ & 10 & $94.70 \pm 1.89$ & $7.31 \pm 0.74$ & $32.25 \pm 0.70^{*, \dagger}$ & $66.67 \pm 1.80^{*, \dagger}$ & $28.02 \pm 1.29^{*, \dagger}$ \\
\hline
\end{tabular}

* : $p<0.001$ (significantly different between the $C_{z}$ and $I_{z}$ )

${ }^{r}: p<0.001$ (significantly different between benthic and water-column species) 

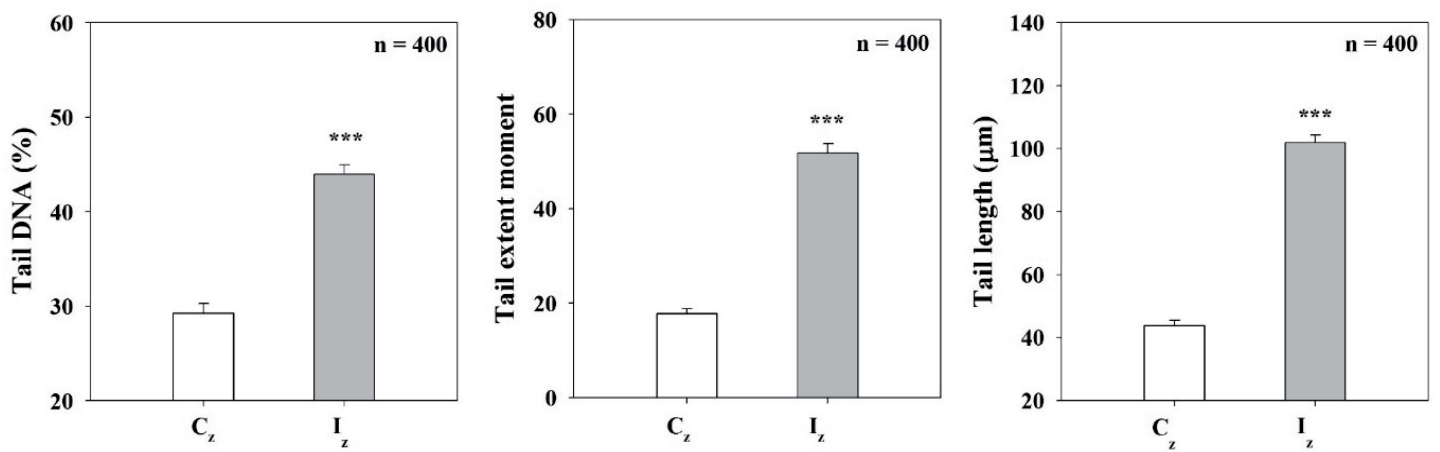

Fig. 2. Overall mean values of tail DNA ( $t \mathrm{DNA})$, tail extent moment $\left(\mathrm{T}_{\mathrm{EM}}\right)$, and tail length $\left(\mathrm{T}_{\mathrm{L}}\right)$ analyzed from two habitat-type fish (watercolumn species vs. benthic species) in the sampling streams; asterisks (***) indicate a significant difference at $p<0.001$ statistically between the $\mathrm{C}_{\mathrm{z}}$ and $\mathrm{I}_{\mathrm{z}}$ by independent two sample $t$-test.

comparison between sampling zones and two habitattype species. Simple linear regression analyses were conducted to examine the relationships among the environmental factors. Statistical analyses were performed at the significant level of $p<0.05$ using the SPSS statistical package (Ver. 21.0).

\section{Results and Discussion}

DNA Damage Assessment

The detections of deoxyribonucleic acid (DNA) damage based on single-cell gel electrophoresis (SCGE) was analyzed at the level of two sentinel fish
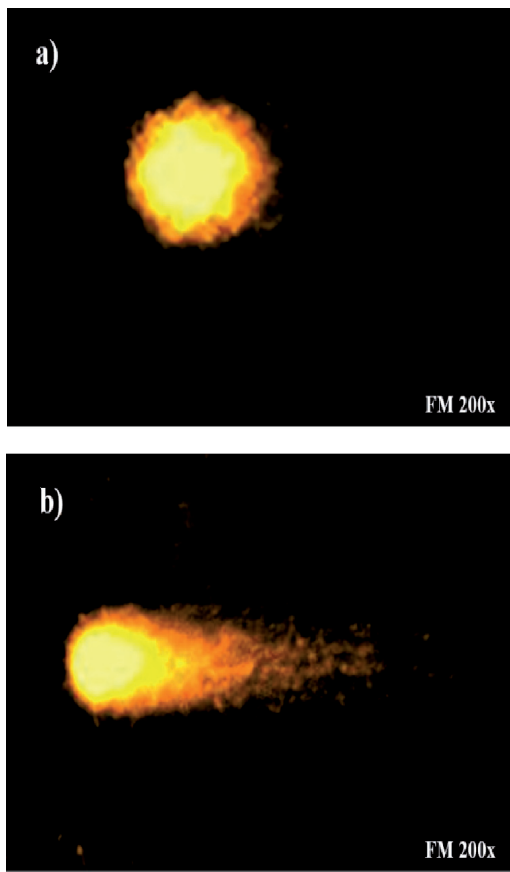

Fig. 3. Nucleus image analysis of blood samples from Zacco platypus as a sentinel species in the control zone $\left(\mathrm{C}_{z}\right.$; a) and the impacted zone $\left(\mathrm{I}_{z} ; \mathrm{b}\right)$ of the sampling streams (Fluorescent microscope 200x). eukaryotic cells as shown in Table 1. Mean tail DNA (tDNA), tail length $\left(\mathrm{T}_{\mathrm{L}}\right)$, and tail extent moment $\left(\mathrm{T}_{\mathrm{EM}}\right)$ of benthic species, Pseudogobio esocinus and watercolumn species, Zacco platypus, were 1.5 times greater in the impacted zone $\left(\mathrm{I}_{\mathrm{z}}\right)$ than in the control zone $\left(\mathrm{C}_{\mathrm{z}}\right)$, and the difference was statistically significant $(p<0.001$; Table 1).

In benthic species, biomarker values of tDNA, $\mathrm{T}_{\mathrm{L}}$, and $\mathrm{T}_{\mathrm{EM}}$ in the $\mathrm{I}_{\mathrm{z}}$ were 2-, 2.1-, and 3.6-fold,
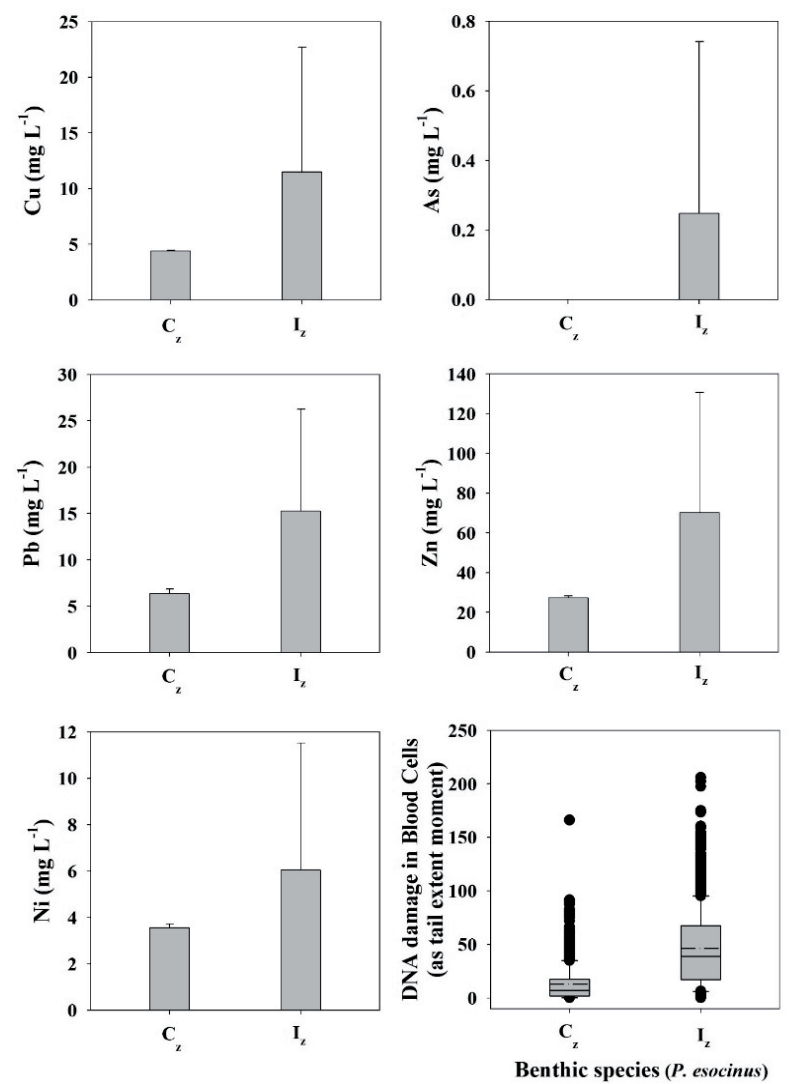

Fig. 4. Heavy metal analyses from bottom sediment samples and DNA damage as tail extent moment in Pseudogobio esocinus from the sampling streams; statistical Mann-Whitney U-tests of all heavy metals were not significant in the level of $p=0.05$ between the $\mathrm{C}_{\mathrm{z}}$ and $\mathrm{I}_{z}$. 
Table 2. Persistent organic pollutants (POPs) in the water samples of the control zone $\left(\mathrm{C}_{\mathrm{z}}\right)$ and Impacted zone (I)); "ND" indicates "notdetected" from the analysis.

\begin{tabular}{|c|c|c|c|c|}
\hline \multirow{2}{*}{\multicolumn{2}{|c|}{ Chemicals of the POPs }} & \multirow{3}{*}{$\frac{\mathrm{C}_{\mathrm{z}}}{\mathrm{N} / \mathrm{D}}$} & \multicolumn{2}{|c|}{$\mathrm{I}_{\mathrm{z}}$} \\
\hline & & & \multirow{2}{*}{$\frac{\text { Mean }}{0.09}$} & \multirow{2}{*}{$\begin{array}{c}\text { Range } \\
0.04-0.24\end{array}$} \\
\hline Agricultural Pesticides & Hexachlorobenzene (ng/L) & & & \\
\hline Aromatic Hydrocarbon & Fluoranthene (ng/L) & $\mathrm{N} / \mathrm{D}$ & 1.35 & $0.8-1.9$ \\
\hline \multirow{2}{*}{ EDCs } & Bisphenol A (ng/L) & $\mathrm{N} / \mathrm{D}$ & 5.50 & $0-22$ \\
\hline & Nonylphenol (ng/L) & $\mathrm{N} / \mathrm{D}$ & 27.75 & $11.5-68$ \\
\hline \multirow{8}{*}{ Herbicides } & Alachlor (ng/L) & $\mathrm{N} / \mathrm{D}$ & 17.43 & $2.81-57.83$ \\
\hline & Metolachlor (ng/L) & $\mathrm{N} / \mathrm{D}$ & 118.25 & $42.7-328.9$ \\
\hline & EN/Dosulfan I (ng/L) & $\mathrm{N} / \mathrm{D}$ & 11.74 & $7.6-65.3$ \\
\hline & EN/Dosulfan II (ng/L) & $\mathrm{N} / \mathrm{D}$ & 4.10 & $1.67-23$ \\
\hline & Atrazine (ng/L) & $\mathrm{N} / \mathrm{D}$ & $\mathrm{N} / \mathrm{D}$ & - \\
\hline & Simazine (ng/L) & $\mathrm{N} / \mathrm{D}$ & 4.45 & $4.73-31.53$ \\
\hline & MCPA (ng/L) & $\mathrm{N} / \mathrm{D}$ & 12.75 & $0-51$ \\
\hline & 2,4-D (ng/L) & $\mathrm{N} / \mathrm{D}$ & 10.00 & $0-31$ \\
\hline \multirow{3}{*}{ Insecticides } & Carbofuran (ng/L) & N/D & 42.75 & $18-135$ \\
\hline & Chlorpyrifos (ng/L) & $\mathrm{N} / \mathrm{D}$ & $\mathrm{N} / \mathrm{D}$ & - \\
\hline & Acenaphthene (ng/L) & $\mathrm{N} / \mathrm{D}$ & 0.88 & $0.8-1.9$ \\
\hline Metabolite of Medicine & Fluorene (ng/L) & N/D & 0.95 & $0.8-2.2$ \\
\hline \multirow{8}{*}{ Metals } & $\mathrm{Cd}(\mathrm{mg} / \mathrm{L})$ & 0.07 & 0.02 & - \\
\hline & $\mathrm{Cu}(\mathrm{mg} / \mathrm{L})$ & 4.38 & 11.51 & - \\
\hline & As $(\mu \mathrm{g} / \mathrm{L})$ & $\mathrm{N} / \mathrm{D}$ & 1.02 & $0.74-1.34$ \\
\hline & $\mathrm{Pb}(\mathrm{mg} / \mathrm{L})$ & 6.35 & 15.27 & - \\
\hline & $\mathrm{Zn}(\mathrm{mg} / \mathrm{L})$ & 27.34 & 70.29 & - \\
\hline & $\mathrm{Ni}(\mathrm{mg} / \mathrm{L})$ & 3.55 & 6.05 & - \\
\hline & $\mathrm{Cr}(\mu \mathrm{g} / \mathrm{L})$ & $\mathrm{N} / \mathrm{D}$ & 0.12 & $0.09-0.17$ \\
\hline & $\mathrm{Hg}(\mu \mathrm{g} / \mathrm{L})$ & N/D & 1.33 & $0.6-2.0$ \\
\hline
\end{tabular}

respectively, than in the $\mathrm{C}_{\mathrm{z}}(p<0.001)$, while in watercolumn species the biomarker values in the $\mathrm{I}_{\mathrm{z}}$ were 1.9-, 2.3-, and 3.9-fold, respectively, than in the $\mathrm{C}_{\mathrm{z}}(p<0.001)$. The magnitude of DNA damage was greater in the benthic species than the water-column species (Table 1). Our results of DNA biomarker indicate that the DNA damages were greater in the $\mathrm{I}_{\mathrm{z}}$ than in the $\mathrm{C}_{\mathrm{z}}$, and that the damage was greater in bottom-feeding fish species with polluted sediments than the water-column fish.

According to single-cell gel electrophoresis of blood samples in two sentinel species with different habitat types, mean tDNA (\%), $\mathrm{T}_{\mathrm{L}}(\mu \mathrm{m})$, and $\mathrm{T}_{\mathrm{EM}}$ had $29.3 \pm 1.0 \%$, $43.8 \pm 1.6 \mu \mathrm{m}, 17.8 \pm 1.0$, respectively (Fig. 2 ). The value of $\mathrm{I}_{z}$ in tDNA was significantly higher $(p<0.001 ; 1.5$ times $)$ than the value of $\mathrm{C}_{\mathrm{z}}(44.0 \pm 1.0 \%)$. Also, values of $\mathrm{I}_{\mathrm{z}}$ in $\mathrm{T}_{\mathrm{L}}$ were significantly higher $(p<0.001 ; 2.3$ times $)$ than the value of $\mathrm{C}_{\mathrm{z}}(101.8 \pm 2.4 \mu \mathrm{m})$, and a similar outcome between $\mathrm{C}_{\mathrm{z}}$ and $\mathrm{I}_{\mathrm{z}}$ was found in $\mathrm{T}_{\mathrm{EM}}(51.7 \pm 2.0 ; 2.9$ times). Numerous research on comet bioassays in polluted streams reported that the main causes of DNA damage in eukaryotic cells of aquatic organisms are closely associated with heavy metals, polyaromatic hydrocarbon (PAHs), agricultural chemicals (pesticides, herbicides) and genotoxicants [55-59].

The magnitude of DNA damage in the blood cells is shown by the results of single-cell gel electrophoresis (SCGE; Fig. 3). Distinct morphological differences in nucleus shapes were contrasted in image analysis of the control zone $\left(\mathrm{C}_{\mathrm{z}}\right)$ and impacted zone $\left(\mathrm{I}_{\mathrm{z}}\right.$ ). The shape of the nucleus in the $\mathrm{C}_{\mathrm{z}}$, based on the single-gel electrophoresis, had circular form and no damage from deoxyribonucleic acid. In contrast, the nucleus in the $\mathrm{I}_{\mathrm{z}}$ had a longitudinal oval form and was composed of small particles broken from the nucleus and scatted longitudinally in the image 
(Fig. 3). The scattered nucleus in the $I_{z}$ indicates that the nucleus moved toward the positive $\stackrel{z}{(})$ polar region by the principles of electrophoresis. The image analysis supported the facts that chemical pollutants influenced DNA damage of fish eukaryotic cells [50-54]. Our results were corroborated by previous research of SCGE bioassays that the magnitude of DNA damage has a functional relationship with concentrations of xenobiotic pollutants [55-57], and the chemical impacts are evident when the breakage of deoxyribonucleic acid is severe, the head part of the nucleus is shorter, and the tail part is longer longitudinally [60-61].

\section{Heavy Metals Assessment}

The analysis of heavy metal concentrations in sediment samples showed that $\mathrm{I}_{\mathrm{z}}$ had higher values than that of $\mathrm{C}_{\mathrm{z}}$ in all heavy metal parameters of $\mathrm{Cu}, \mathrm{As}, \mathrm{Pb}$, $\mathrm{Zn}$, and $\mathrm{Ni}$ (Fig. 4). High heavy metal values of $\mathrm{I}_{\mathrm{z}}$ from the sediments agreed with total mercury concentrations in fish tissues. Statistical analysis of Mann-Whitney U-tests, however, showed that there were no significant differences in the heavy metals of $\mathrm{Cu}, \mathrm{As}, \mathrm{Pb}, \mathrm{Zn}$ and $\mathrm{Ni}$ between the control and impacted zones (Fig. 4). The reason turned out to be high variabilities between the samples and the low number of observations in the metal analysis. In the comet assay of DNA damage (tail DNA, tail moments, DNA tail length), the total number of observations were 400 samples, but the number of the heavy metal samples in the sediment were very few $(\mathrm{n}=6)$. In addition, sample variation in the sediments was highly contingent on the silt or sand percentages at the study locations. Therefore, the outcomes of these metals showed no significance between the control and impacted zones [62].

\section{Persistent Organic Pollutants (POPs) Assessments}

In the meantime, the analysis of persistent organic pollutants (POPs) showed that the hazard chemicals in the water samples were not detected in the control zone, but significant amounts of chemicals were detected in the impacted zone as shown in Table 2. The herbicide concentrations of metolachlor averaged $118.25 \mathrm{ng} / \mathrm{L}$ in the $\mathrm{I}_{\mathrm{z}}$, compared to "not detected" in the $\mathrm{C}_{\mathrm{z}}$. Also, bisphenol-A and nonylphenol, which are known as endocrine-disrupting chemicals (EDCs) in waterbodies, were $5.5 \mathrm{ng} / \mathrm{L}$ (range; 0-22 ng/L) and $27.75 \mathrm{ng} / \mathrm{L}$ (range; 11.5-68.0 $\mathrm{ng} / \mathrm{L}$ ), respectively in the impacted zone, while the chemicals were not detected in the $\mathrm{C}_{\mathrm{z}}$. Also, heavy metals of $\mathrm{Cr}$ and $\mathrm{Hg}$ in the water samples were $1.12 \mathrm{ug} / \mathrm{L}$ and $1.33 \mathrm{ug} / \mathrm{L}$, respectively in the impacted zone, unlike the no-detections in the control zone. The persistent organic pollutants might have influenced the DNA damages and physiological responses of fish. In fact, Adams et al. [18] and Adams [40] pointed out that agricultural herbicide, pesticide and the EDCs resulted in repressions of RNA expression and synthesis and the DNA damage in fish, thus the alterations of these molecular levels influenced the fish population and community in the end. Similar results are shown in the paper of [63-65]. Our results and these references suggested that the persistent organic pollutants potentially influenced the DNA damages and EROD activities.

\section{Detection of Physiological Activities Based on 7-ethoxyresorufin-O-deethylase (EROD) Activity}

Physiological activities based on 7-ethoxyresorufin$O$-deethylase (EROD) activity were analyzed using two sentinel species of benthic fish: Pseudogobio esocinus and the water-column dwelling fish Zacco platypus (Fig. 5). The response of EROD activity was greater in the water-column species; the response of water-column dwelling species was 11-fold higher in the $I_{z}$ than the $\mathrm{C}_{\mathrm{z}}(p<0.001)$. Also, the response of benthic species was 2.1 -fold higher in the $\mathrm{I}_{\mathrm{z}}$ than the $\mathrm{C}_{\mathrm{z}}(p<0.001)$. These outcomes indicate that the physiological response of the $\mathrm{I}_{\mathrm{z}}$ increased up to 3.8 times in the EROD activity on average, compared to the response of $\mathrm{C}_{\mathrm{z}}$, and the statistical difference was significant $(p<0.01)$. Adams et al. [18] pointed out that such increases in EROD activity are frequently attributed to physical factors of an aquatic ecosystem such as water temperature, $\mathrm{pH}$, and physical disturbance, and occurred by some exposures of certain chemical contaminants such as polycyclic
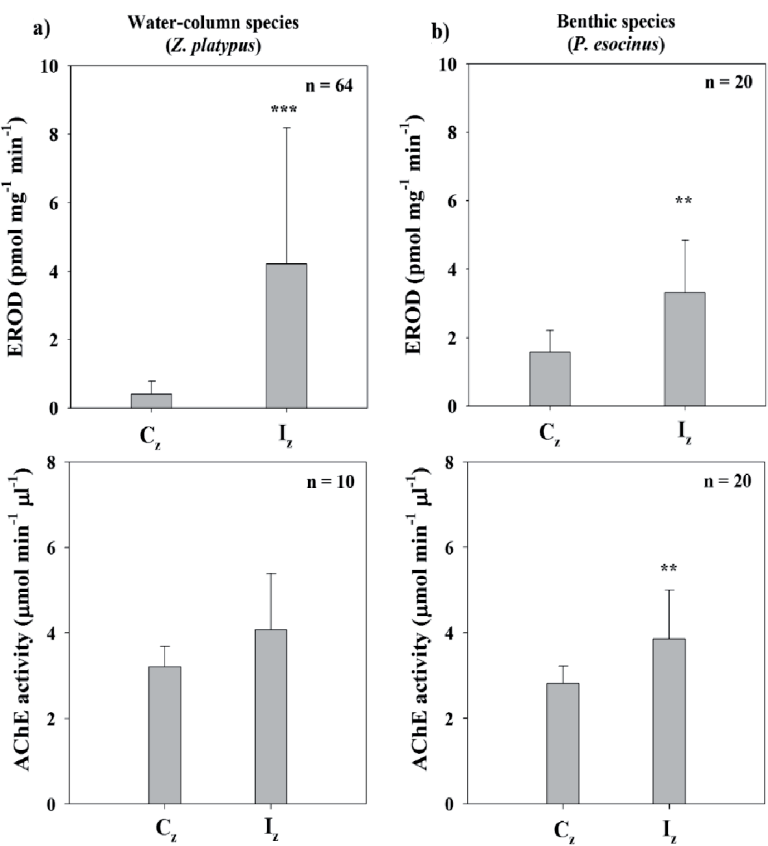

Fig. 5. Physiological responses of two different biomarkers of 7-ethoxyresorufin- $O$-deethylase (EROD) activity and acetylcholinesterase (AChE) in the water-column (Zacco platypus) and benthic (Pseudogobio esocinus) species in the control $\left(\mathrm{C}_{\mathrm{z}}\right)$ and impacted $\left(\mathrm{I}_{\mathrm{z}}\right)$ zones of the sampling streams; a) panel and b) panel indicate water-column species and benthic species, respectively $(* * *=p<0.001$ and $* *=p<0.01$ as significantly differences between the $\mathrm{C}_{\mathrm{z}}$ and $\mathrm{I}_{\mathrm{z}}$ ) 
aromatic hydrocarbons (PAHs) and polychlorinated biphenyls (PCBs) [66-67]. Therefore, we believe that the increases in EROD activity in the $\mathrm{I}_{\mathrm{z}}$ seemed to be influenced by habitat modifications or some chemical pollutants, which are directly discharged from urban regions, industrial complexes and sewage disposal plants. In fact, the impacted zone of our streams has big point sources of wastewater disposal plants (WDP) discharging about $9 \times 10^{5} \mathrm{~m}^{3}$ day $^{-1}$, and the Daejeon industrial complex, so the effluents increased the activity of EROD in the polluted zone.

\section{Detection of Physiological Activities Based on Acetylcholinesterase (AChE) Activity}

The physiological response of acetylcholinesterase (AChE) activity was measured in the benthic fish Pseudogobio esocinus and the water-column-dwelling fish Zacco platypus (Fig. 5). The response of AChE activity in the water-column species was approximately 1.4-fold higher in the $\mathrm{I}_{\mathrm{z}}$ than in the $\mathrm{C}_{\mathrm{z}}$, and the statistical difference in the response was significant $(p<0.05)$ between the two zones. In the meantime, in benthic species the response of $\mathrm{C}_{\mathrm{z}}$ and $\mathrm{I}_{\mathrm{z}}$ was $2.81 \pm 0.41$ and $3.86 \pm 1.14 \mu \mathrm{mol} \min ^{-1} \mu \mathrm{l}^{-1}$, respectively, indicating a greater response of 1.4 -fold in the impacted zone $(p<0.01)$. These responses of AChE were similar to the response of EROD activity, but showed higher sensitivity than the EROD activity in both water-column species and benthic species. The physiological response of AChE is generally increased primarily by neurotoxins [66-71]. Our measured AChE activity showed significantly greater response in the $\mathrm{I}_{z}$. We did not measure the neurotoxins in our study. It was considered that AChE activity had increased due to increased exposure of contaminants, which can influence the nervous system as passing through urban areas, industrial areas and sewage disposal plants [62, 71-73].

\section{Conclusions}

We carried out the ecological risk assessment in two streams by the combined application of DNA damages in selected fish species used as biomarkers at multi-levels as well as studied the change in their physiological responses. The obtained results of applied biomarkers of tDNA, $T_{L}$, and TEM in the $I_{z}$ showed as 2.0-3.6-fold greater as compared to the control zone $\left(C_{z}\right)$. Furthermore, the nucleus displayed circular particle formations in the $\mathrm{C}_{\mathrm{z}}$ in comparison to the longitudinal oval forms with broken particles in the nucleus from the $\mathrm{I}_{\mathrm{z}}$. Similarly, the physiological responses signposted the higher levels in the $\mathrm{I}_{\mathrm{z}}$ than in the $\mathrm{C}_{\mathrm{z}}$. Such discrepancies in the biomarkers of DNA damages as well as physiological responses in the $\mathrm{I}_{\mathrm{z}}$ could be linked to chemical discharges from WWTPs and industrial complexes. Overall, this combined approach of using the DNA damages and physiological responses could become a vital tool in early-warning detection of impending chemicals in urban streams.

\section{Author Contributions}

Bae DU collected the data, carried out the laboratory procedures and prepared the manuscript with Atique U. Yoon JH and Lim BJ. helped in data analysis and manuscript preparation. An KG supervised the whole study.

\section{Acknowledgments}

This study was financially supported by the Basic Environmental Research Program of the Geum River System, (NIER-2018), the Ministry of the Environment, Korea and the Daejeon Green Environment Center under the Research Development Program (Year 2017); thus, the author would like to acknowledge these institutions for their assistance.

\section{Conflicts of Interest}

The authors declare no conflicts of interest.

\section{References}

1. CONNON R.E., GEIST J., WERNER I. Effect-based tools for monitoring and predicting the ecotoxicological effects of chemicals in the aquatic environment. Sensors. 12, 12741, 2012.

2. BAUDOU F.G., OSSANA N.A., CASTAÑÉ P.M., MASTRÁNGELO M.M., GONZÁLEZ NÚÑEZ A.A., PALACIO M.J., FERRARI L. Use of integrated biomarker indexes for assessing the impact of receiving waters on a native neotropical teleost fish. Science of The Total Environment, 650, 1779, 2019.

3. CHAPMAN P.M. Determining when contamination is pollution - Weight of evidence determinations for sediments and effluents. Environ. Int., 33, 492, 2007.

4. KROON F., STRETEN C., HARRIES S.A. Protocol for identifying suitable biomarkers to assess fish health: A systematic review. PLOS ONE, 12 (4), e0174762. 2017.

5. OLIVE P.L., BANÁTH J.P. The comet assay: a method to measure DNA damage in individual cells. Nat. Protoc. 1, 23, 2006.

6. NEHLS S., SEGNER H. Comet Assay with the Fish Cell Line Rainbow Trout Gonad-2 for Invitro Genotoxicity Testing of Xenobiotics and Surface Waters. Environ. Toxicol. Chem. 24, 2078, 2005.

7. BELPAEME K., COOREMAN K., KIRSCH-VOLDERS M. Development and validation of the in vivo alkaline comet assay for detecting genomic damage in marine flatfish. Mutat. Res-Gen. Tox. En., 415, 167, 1998.

8. PANDEY A.K., NAGPURE N.S., TRIVEDI S.P. Genotoxicity assessment of pesticide profenofos in freshwater fish Channa punctatus (Bloch) using comet 
assay and random amplified polymorphic DNA (RAPD). Chemosphere, 211, 316, 2018.

9. COLLINS A.R. The comet assay for DNA damage and repair. Mol. Biotechnol., 26, 249, 2004.

10. SEGNER H., WENGER M., MÖLLER A.M., KÖLLNER B., CASANOVA-NAKAYAMA A. Immunotoxic effects of environmental toxicants in fish - how to assess them? Environmental Science and Pollution Research, 19(7), 2465, 2012

11. ÖSTLING O., JOHANSON K. Microelectrophoretic study of radiation-induced DNA damages in individual mammalian cells. Biochem. Bioph. Res. Co., 123, 291, 1984.

12. SINGH N.P., MCCOY M.T., TICE R.R., SCHNEIDER E.L. A simple technic for quantitation of low levels of DNA damage in individual cells. Exp. Cell. Res., 175, 184, 1988.

13. LIVINGSTONE D.R. Biotechnology and pollution monitoring: use of molecular biomarkers in the aquatic environment. J. Chem. Technol. Biot., 57, 195, 1993.

14. LI Z.-H., ZLABEK V., VELISEK J., GRABIC R., MACHOVA J., KOLAROVA J., LI P., RANDAK T. Multiple biomarkers responses in juvenile rainbow trout, Oncorhynchus mykiss, after acute exposure to a fungicide propiconazole. Environmental Toxicology, 28 (3), 119. 2013.

15. DUTTA H.M., ARENDS D.A. Effects of endosulfan on brain acetylcholinesterase activity in juvenile bluegill sunfish. Environ. Res. 91, 157, 2003.

16. MENÉNDEZ-HELMAN R.J., FERREYROA G.V., DOS SANTOS AFONSO M., SALIBIÁN A. Circannual rhythms of acetylcholinesterase (AChE) activity in the freshwater fish Cnesterodon decemmaculatus. Ecotoxicology and Environmental Safety, 111, 236, 2015.

17. WHYTE J.J., JUNG R.E., SCHMITT C.J., TILLITT D.E. Ethoxyresorufin- $O$-deethylase (EROD) activity in fish as a biomarker of chemical exposure. Crit. Rev. Toxicol., 30, 347, 2000.

18. ADAMS S.M., BROWN A.M., GOEDE R.W. A quantitative health assessment index for rapid evaluation of fish condition in the field. T. Am. Fish. Soc., 122, 63, 1993.

19. BAUDOU F.G., OSSANA N.A., CASTAÑÉ P.M., MASTRÁNGELO M.M., GONZÁLEZ NÚÑEZ A.A., PALACIO M.J., FERRARI L. Use of integrated biomarker indexes for assessing the impact of receiving waters on a native neotropical teleost fish. Science of The Total Environment, 650, 1779, 2019.

20. MOON W.-K., ATIQUE U., AN K.-G. Ecological risk assessments and eco-toxicity analyses using chemical, biological, physiological responses, DNA damages and gene-level biomarkers in Zebrafish (Danio rerio) in an urban stream. Chemosphere, 239, 124754, 2019 doi:10.1016/j.chemosphere.2019.124754.

21. ATIQUE U., BYUNGJIN L., JOHEE Y., AN K.-G. Biological Health Assessments of Lotic Waters by Biotic Integrity Indices and their Relations to. Water, 11, 436. 2019. doi:10.3390/w11030436.

22. CHOI J.W., HAN J.H., PARK C.S., KO D.G., KANG H-I., KIM J.Y., YUN Y-J., KWON H-H., AN K.G. Nutrients and sestonic chlorophyll dynamics in Asian lotic ecosystems and ecological stream health in relation to land-use patterns and water chemistry. Ecological Engineering, 79, 15, 2015.

23. KIM J.-J., ATIQUE U., AN K.-G. Long-Term Ecological Health Assessment of a Restored Urban Stream Based on
Chemical Water Quality, Physical Habitat Conditions and Biological Integrity. Water, 11 (1), 114. 2019.

24. ATIQUE U., AN K.-G. Stream Health Evaluation Using a Combined Approach of Multi-Metric Chemical Pollution and Biological Integrity Models. Water, 10, 661, 2018.

25. KIM J., AN K.-G. Integrated Ecological River Health Assessments, Based on Water Chemistry, Physical Habitat Quality and Biological Integrity. Water, 7 (11), 6378. 2015.

26. ATIQUE U., AN K.-G. Reservoir Water Quality Assessment Based on Chemical Parameters and the Chlorophyll Dynamics in Relation to Nutrient Regime. Polish Journal of Environmental Studies, 28 (3), 1043, 2018.

27. LEE J.H., AN K.-G. Integrative restoration assessment of an urban stream using multiple modeling approaches with physical, chemical, and biological integrity indicators. Ecological Engineering, 62, 15, 2014.

28. LEE S.-J., LEE E.-H., AN K.-G. Lotic Ecosystem Health Assessments Using an Integrated Analytical Approach of Physical Habitat, Chemical Water Quality, and Fish MultiMetric Health Metrics. Polish Journal of Environmental Studies, 27 (5), 2113, 2018.

29. U.S. E.P.A. Summary of biological assessment programs and biocriteria development for states, tribes, territories, and interstate commissions: streams and wadable river. EPA-822-R-02-048. US EPA, USA. 2002.

30. BLANFUNÉ A., THIBAUT T., BOUDOURESQUE C.F., MAČIĆ V., MARKOVIC L., PALOMBA L., VERLAQUE M., BOISSERY P. The CARLIT method for the assessment of the ecological quality of European Mediterranean waters: Relevance, robustness and possible improvements. Ecological Indicators, 72, 249, 2017.

31. MOGES A., BEYENE A., KELBESSA E., MERETA S.T., AMBELU A. Development of a multimetric plant-based index of biotic integrity for assessing the ecological state of forested, urban and agricultural natural wetlands of Jimma Highlands, Ethiopia. Ecological Indicators, 71, 208, 2016.

32. HUGUENY B., CAMARA S., SAMOURA B., MAGASSOUBA M. Applying an index of biotic integrity based on communities in a West African river. Hydrobiologia, 331, 71, 1996.

33. KIM J.H., YEOM D.H., AN K.G. A new approach of Integrated Health Responses (IHRs) modeling or ecological risk/health assessments of an urban stream. Chemosphere, 108, 376, 2014.

34. JANG G.-S., AN K.-G. Physicochemical water quality characteristics in relation to land use pattern and point sources in the basin of the Dongjin River and the ecological health assessments using a fish multi-metric model. J. Ecol. Environ., 40 (6), 2016. doi:10.1186/s41610016-0011-2

35. AN K.G., KIM D.S., KONG D.S., KIM S.D. Integrative assessments of a temperate stream based on a multimetric determination of biological integrity, physical habitat evaluations, and toxicity tests. B. Environ. Contam. Toxicol., 73, 471, 2004.

36. CALDERON M.S., AN K.-G. An influence of mesohabitat structures (pool, riffle, and run) and land-use pattern on the index of biological integrity in the Geum River watershed. J. Ecol. Environ., 40 (13), 2016. doi:10.1186/ s41610-016-0018-8

37. MØLLER P., KNUDSEN L.E., LOFT S., WALLIN H. The comet assay as a rapid test in biomonitoring occupational exposure to DNA-damaging agents and effect of 
confounding factors. Cancer Epidemiol. Biomarkers Prev., 9, 1005, 2000.

38. QUESADA-GARCÍA A., VALDEHITA A., KROPF C., CASANOVA-NAKAYAMA A., SEGNER H., NAVAS J.M. Thyroid signaling in immune organs and cells of the teleost fish rainbow trout (Oncorhynchus mykiss). Fish \& Shellfish Immunology, 38 (1), 166, 2014.

39. KHAN N., ATIQUE U., ASHRAF M., MUSTAFA A., MUGHAL M.S., RASOOL F., AZMAT H., TAYYAB M., IQBAL K.J. Effect of Various Protein Feeds on the Growth, Body Composition, Hematology and Endogenous Enzymes of Catfish (Pangasius hypophthalmus). Pakistan Journal of Zoology, Suppl. Ser. (13), 112, 2018.

40. ADAMS S.M. Biomarker/bioindicator response profiles of organisms can help differentiate between sources of anthropogenic stressors in aquatic ecosystems. Biomarkers, 6, 33, 2001.

41. WANG C., HARWOOD J.D., ZHANG Q. Oxidative stress and DNA damage in common carp (Cyprinus carpio) exposed to the herbicide mesotrione. Chemosphere, 193, 1080, 2018.

42. FRENZILLI G., NIGRO M., LYONS B.P. The Comet assay for the evaluation of genotoxic impact in aquatic environments. Mutat. Res., 681, 80, 2009.

43. IQBAL S., ATIQUE U., MUGHAL M.S., KHAN N., HAIDER M.S., IQBAL K.J., AKMAL M. Effect of Selenium Incorporated in Feed on the Hematological Profile of Tilapia (Oreochromis niloticus). Journal of Aquaculture Research and Development, 8 (9), 1000513, 2017. Doi: $10.4172 / 2155-9546.1000513$

44. ZHANG L., SHI Z., JIANG Z., ZHANG J., WANG F., HUANG X. Distribution and bioaccumulation of heavy metals in marine organisms in east and west Guangdong coastal regions, South China. Marine Pollution Bulletin, 101 (2), 930, 2015.

45. SAYED A.E.-D.H., WATANABE-ASAKA T., ODA S., KASHIWADA S., MITANI H. $\gamma$-H2AX foci as indication for the DNA damage in erythrocytes of medaka (Oryzias latipes) intoxicated with 4-nonylphenol. Environmental Science and Pollution Research, https://doi.org/10.1007/ s11356-018-2985-z 2018.

46. VIEIRA C.E.D., PÉREZ M.R., ACAYABA R.D., RAIMUNDO C.C.M., DOS REIS MARTINEZ C.B. DNA damage and oxidative stress induced by imidacloprid exposure in different tissues of the Neotropical fish Prochilodus lineatus. Chemosphere, 195, 125. 2018.

47. KIM I.S., PARK J.Y. Freshwater fish of Korea. Kyo-Hak Publishing Co., Seoul, South Korea. 2002.

48. AN K.G., LEE J.Y., BAE D.Y., KIM J.H., HWANG S.J., WON D.H., LEE J.K., KIM C.S. Ecological assessments of aquatic environment using multi-metric model in major nationwide stream watersheds. J. Korean Soc. Water Qual., 22, 796, 2006.

49. MOE/NIER. (The Ministry of Environment / National Institute of Environmental Research). The Survey and Evaluation of Aquatic Ecosystem Health in Korea; The Ministry of Environment/National Institute of Environmental Research (NIER): Incheon, Korea, 2008.

50. OHIO. E.P.A. Biological Criteria for the Protection of Aquatic Life. Volume III: Standardized Biological Field Sampling and Laboratory Methods for Assessing Fish and Macroinvertebrate Communities. Ohio Environmental Protection Agency, Columbus, Ohio, USA. 1989.

51. KENNEDY S.W., JONES S.P. Simultaneous measurement of cytochrome P4501A catalytic activity and total protein concentration with a fluorescence plate reader. Anal. Biochem., 222 (1), 217, 1994.

52. ELLMAN G.L., COURTNEY K.D., ANDRES V., FEATHERSTONE R.M. A new and rapid colorimetric determination of acetylcholinesterase activity. Biochem. Pharmacol., 7, 88, 1961.

53. EATON A.D., FRANSON M.A.H. Standard Methods for the Examination of Water and Wastewater. American Public Health Association, Washington, D.C. 2005.

54. SEGNER H., WENGER M., MÖLLER A.M., KÖLLNER B., CASANOVA-NAKAYAMA A. Immunotoxic effects of environmental toxicants in fish : how to assess them? Environmental Science and Pollution Research, 19 (7), 2465, 2012.

55. HARIHARAN G., PURVAJA R., RAMESH R. Environmental safety level of lead $(\mathrm{Pb})$ pertaining to toxic effects on grey mullet (Mugil cephalus ) and Tiger perch (T. erapon jarbua). Environmental Toxicology, 31 (1), 24, 2016.

56. PICADO A., BEBIANNO M.J., COSTA M.H., FERREIRA A., VALE C. Biomarkers: a strategic tool in the assessment of environmental quality of coastal waters. Hydrobiologia, 587, 79, 2007

57. KROON F., STRETEN C., HARRIES S. A protocol for identifying suitable biomarkers to assess fish health: A systematic review. PLOS ONE, 12 (4), e0174762, 2017.

58. SAYED A.E.-D.H., MOHAMED N.H., ISMAIL M.A., ABDEL-MAGEED W.M., SHOREIT A.A.M. Antioxidant and antiapoptotic activities of Calotropis procera latex on Catfish (Clarias gariepinus) exposed to toxic 4-nonylphenol. Ecotoxicology and Environmental Safety, 128, 189, 2016

59. BEG M.U., AL-JANDAL N., AL-SUBIAI S., KARAM Q., HUSAIN S., BUTT S.A., ALI A., AL-HASSAN E., AL-DUGAILEEJ S., AL-HUSAINI M. Metallothionein, oxidative stress and trace metals in gills and liver of demersal and pelagic fish species from Kuwaits' marine area. Marine Pollution Bulletin, 100 (2), 662, 2015.

60. RAMSDORF W.A., VICARI T., DE ALMEIDA M.I.M., ARTONI R.F., CESTARI M.M. Handling of Astyanax sp. for biomonitoring in Cangüiri Farm within a fountainhead (Iraí River Environment Preservation Area) through the use of genetic biomarkers. Environmental Monitoring and Assessment, 184 (10), 5841, 2012.

61. KALANTZI I., PAPAGEORGIOU N., SEVASTOU K., BLACK K.D., PERGANTIS S. A., KARAKASSIS I. Metals in benthic macrofauna and biogeochemical factors affecting their trophic transfer to wild fish around fish farm cages. Science of The Total Environment, 470-471, 742, 2014.

62. MARTIN J.M., BERTRAM M.G., SAARISTO M., ECKER T.E., HANNINGTON S.L., TANNER J.L., MICHELANGELI M., O'BRYAN M.K., WONG B.B.M. Impact of the widespread pharmaceutical pollutant fluoxetine on behaviour and sperm traits in a freshwater fish. Science of The Total Environment, 650, 1771. 2019.

63. MEKKAWY I.A., MAHMOUD U.M., SAYED A.E.-D.H. Effects of 4-nonylphenol on blood cells of the African catfish Clarias gariepinus (Burchell, 1822). Tissue and Cell, 43 (4), 223, 2011.

64. PÉREZ-COYOTL I., MARTÍNEZ-VIEYRA C., GALARMARTÍNEZ M., GÓMEZ-OLIVÁN L.M., GARCÍAMEDINA S., ISLAS-FLORES H., PÉREZ-PASTEN BORJA R., GASCA-PÉREZ E., NOVOA-LUNA K.A., DUBLÁN-GARCÍA O. DNA damage and cytotoxicity 
induced on common carp by pollutants in water from an urban reservoir. Madín reservoir, a case study. Chemosphere, 185, 789, 2017.

65. PANDEY A.K., NAGPURE N.S., TRIVEDI S.P. Genotoxicity assessment of pesticide profenofos in freshwater fish Channa punctatus (Bloch) using comet assay and random amplified polymorphic DNA (RAPD). Chemosphere, 211, 316. 2018.

66. HOOK S.E., GALLAGHER E.P., BATLEY G.E. The role of biomarkers in the assessment of aquatic ecosystem health. Integrated Environmental Assessment and Management, 10 (3), 327, 2014.

67. FONSECA V.F., VASCONCELOS R.P., FRANÇA S., SERAFIM A., LOPES B., COMPANY R., BEBIANNO M.J., COSTA M.J., CABRAL H.N., CABRAL H.N. Modeling fish biological responses to contaminants and natural variability in estuaries. Marine Environmental Research, 96, 45, 2014.

68. AWASTHI Y., RATN A., PRASAD R., KUMAR M., TRIVEDI S. P. An in vivo analysis of $\mathrm{Cr} 6+$ induced biochemical, genotoxicological and transcriptional profiling of genes related to oxidative stress, DNA damage and apoptosis in liver of fish, Channa punctatus (Bloch, 1793). Aquatic Toxicology, 200, 158, 2018.

69. VIEIRA C.E.D., ALMEIDA M.DA.S., GALINDO B.A., PEREIRA L., MARTINEZ C.B.D.R. Integrated biomarker response index using a Neotropical fish to assess the water quality in agricultural areas. Neotropical Ichthyology, 12 (1), 153, 2014

70. HUSSAIN B., SULTANA T., SULTANA S., MASOUD M.S., AHMED Z., MAHBOOB S. Fish ecogenotoxicology: Comet and micronucleus assay in fish erythrocytes as in situ biomarker of freshwater pollution. Saudi journal of biological sciences, 25 (2), 393, 2018.

71. ROSSI S.C., DREYER DA SILVA M., PIANCINI L.D.S., OLIVEIRA RIBEIRO C.A., CESTARI M.M., SILVA DE ASSIS H.C. Sublethal Effects of Waterborne Herbicides in Tropical Freshwater Fish. Bulletin of Environmental Contamination and Toxicology, 87 (6), 603, 2011.

72. BARŠIENĖ J., RYBAKOVAS, A., LANG, T., ANDREIKĖNAITE், L., \& MICHAILOVAS, A. Environmental genotoxicity and cytotoxicity levels in fish from the North Sea offshore region and Atlantic coastal waters. Marine Pollution Bulletin, 68 (1-2), 106, 2013.

73. HEMALATHA, D., AMALA A., RANGASAMY B., NATARAJ B., RAMESH M. Sublethal toxicity of quinalphos on oxidative stress and antioxidant responses in a freshwater fish Cyprinus carpio. Environmental Toxicology, 31 (11), 1399, 2016. 